\title{
Urokinase-Derived Peptide A6
}

National Cancer Institute

\section{Source}

National Cancer Institute. Urokinase-Derived Peptide A6. NCI Thesaurus. Code C91709.

An octapeptide (amino acids 136-143) derived from the proteolytic enzyme urokinase plasminogen activator (UPA), with potential antineoplastic activity. A6 is derived from the nonreceptor-binding domain and connecting region of urokinase. Administration of A6 inhibits the interaction of UPA with its receptor UPAR, and may inhibit endothelial cell motility and tumor cell invasion. UPA and UPAR promote extracellular matrix degradation and growth factor activation and correlate positively with angiogenesis, cancer cell invasion and metastasis. 